\title{
Comparison of infection control strategies to reduce COVID-19 outbreaks in homeless shelters in the United States: a simulation study
}

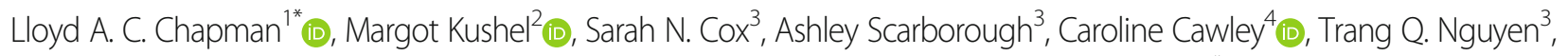
Isabel Rodriguez-Barraquer ${ }^{1}$ (D), Bryan Greenhouse ${ }^{1}$ (D) Elizabeth Imbert ${ }^{5}$ and Nathan C. Lo ${ }^{1^{*}}$ (D)

\begin{abstract}
Background: COVID-19 outbreaks have occurred in homeless shelters across the US, highlighting an urgent need to identify the most effective infection control strategy to prevent future outbreaks.

Methods: We developed a microsimulation model of SARS-CoV-2 transmission in a homeless shelter and calibrated it to data from cross-sectional polymerase chain reaction (PCR) surveys conducted during COVID-19 outbreaks in five homeless shelters in three US cities from March 28 to April 10, 2020. We estimated the probability of averting a COVID-19 outbreak when an exposed individual is introduced into a representative homeless shelter of 250 residents and 50 staff over 30 days under different infection control strategies, including daily symptom-based screening, twice-weekly PCR testing, and universal mask wearing.

Results: The proportion of PCR-positive residents and staff at the shelters with observed outbreaks ranged from 2.6 to $51.6 \%$, which translated to the basic reproduction number $\left(R_{0}\right)$ estimates of 2.9-6.2. With moderate community incidence $(\sim 30$ confirmed cases/1,000,000 people/day), the estimated probabilities of averting an outbreak in a low-risk $\left(R_{0}=1.5\right)$, moderate-risk $\left(R_{0}=2.9\right)$, and high-risk $\left(R_{0}=6.2\right)$ shelter were respectively $0.35,0.13$, and 0.04 for daily symptom-based screening; $0.53,0.20$, and 0.09 for twice-weekly PCR testing; $0.62,0.27$, and 0.08 for universal masking; and $0.74,0.42$, and 0.19 for these strategies in combination. The probability of averting an outbreak diminished with higher transmissibility $\left(R_{0}\right)$ within the simulated shelter and increasing incidence in the local community.
\end{abstract}

Conclusions: In high-risk homeless shelter environments and locations with high community incidence of COVID-19, even intensive infection control strategies (incorporating daily symptom screening, frequent PCR testing, and universal mask wearing) are unlikely to prevent outbreaks, suggesting a need for non-congregate housing arrangements for people experiencing homelessness. In lower-risk environments, combined interventions should be employed to reduce outbreak risk.

Keywords: COVID-19, SARS-CoV-2, Homelessness, Shelters, Infection control, Outbreaks, Symptom-based screening, PCR testing, Universal masking

\footnotetext{
* Correspondence: Lloyd.Chapman@ucsf.edu; Nathan.Lo@ucsf.edu 'Department of Medicine, University of California, San Francisco, San Francisco, CA 94110, USA

Full list of author information is available at the end of the article
}

(c) The Author(s). 2021 Open Access This article is licensed under a Creative Commons Attribution 4.0 International License, which permits use, sharing, adaptation, distribution and reproduction in any medium or format, as long as you give appropriate credit to the original author(s) and the source, provide a link to the Creative Commons licence, and indicate if changes were made. The images or other third party material in this article are included in the article's Creative Commons licence, unless indicated otherwise in a credit line to the material. If material is not included in the article's Creative Commons licence and your intended use is not permitted by statutory regulation or exceeds the permitted use, you will need to obtain permission directly from the copyright holder. To view a copy of this licence, visit http://creativecommons.org/licenses/by/4.0/ The Creative Commons Public Domain Dedication waiver (http://creativecommons.org/publicdomain/zero/1.0/) applies to the data made available in this article, unless otherwise stated in a credit line to the data. 


\section{Background}

The coronavirus disease 2019 (COVID-19) pandemic caused by infection with severe acute respiratory syndrome coronavirus 2 (SARS-CoV-2) poses a great risk to people experiencing homelessness. Across the United States (US), the estimated 568,000 people who experience homelessness nightly [1] are likely to suffer a disproportionate disease burden and need for hospitalization [2,3]. People experiencing homelessness are on average older and have a high prevalence of comorbidities that are risk factors for severe COVID-19 [2]. Multiple outbreaks in homeless shelters have occurred in several cities, including San Francisco, Boston, Seattle, Atlanta, and Los Angeles, with attack rates of up to $67 \%$ [4-8]. Homeless shelters have remained open in many cities despite the high incidence of infection in the community, concern about the risk of further outbreaks, and uncertainty over the effectiveness of different infection control strategies. There is an immediate need to identify the best infection control strategy to reduce the risk of outbreaks and assess the safety of continuing to operate congregate shelters where transmission in the community is high.

The role of shelters and associated infection control practices in the transmission of COVID-19 among people experiencing homelessness is still poorly understood. Given the current understanding that the SARSCoV-2 virus is transmitted predominantly through respiratory droplets, with some airborne transmission [9], there is a need to consider policies to limit transmission within high-density congregate living environments. Different infection control strategies are currently recommended based on the level of transmission in the external community [10]. These include routine symptom screening, polymerase chain reaction (PCR) testing, universal mask wearing, and relocation of individuals at high risk of severe disease to non-congregate settings [11]. There is limited evidence on the effectiveness of strategies to reduce transmission in congregate settings, and thus, further research is urgently needed to guide city-level policy across the US.

The goal of this study is to identify the most effective infection control strategy to slow the spread of COVID19 among people experiencing homelessness who reside in shelters. We address this pressing question by estimating the comparative health outcomes of key infection control strategies using a simulation model calibrated to data on homeless shelter outbreaks.

\section{Methods}

\section{Microsimulation model}

We developed an individual-level stochastic susceptibleexposed-infectious-recovered (SEIR) model [12] to simulate the transmission of SARS-CoV-2 in a congregate shelter population (Additional file 1: Figure S1) [4-7, 9,
13-75]. The model defines individuals as susceptible, exposed, infectious, or immune to SARS-CoV-2 (Additional file 1: Table S1). We constructed the model to include important aspects of the natural history of COVID-19, including sub-clinical infection, pre-symptomatic transmission, and age-specific differences in the risk of severe symptoms (see Additional file 1 for full details). In the model, susceptible individuals become infected with SARS-CoV-2 at a rate proportional to the prevalence of infectious individuals inside the shelter and their infectiousness (assuming homogeneous mixing), plus a static force of infection based on the background infection incidence in the community outside the shelter. Upon infection, individuals enter a latent infection stage in which they incubate the virus but are not infectious. They then progress to become infectious and contribute to ongoing transmission. An age-dependent fraction of infected individuals develop clinical symptoms with an associated risk of hospitalization and death (Additional file 1: Table S2), while the remainder have subclinical infection. Individuals who recover from infection are assumed to remain immune.

\section{Data}

The model was calibrated using aggregate data from PCR testing conducted during COVID-19 outbreaks in five shelters in three US cities-San Francisco $(n=1)$, Boston $(n=1)$, and Seattle $(n=3)[4,6,7]$-from March 28 to April 10, 2020. We obtained de-identified individual-level data from the outbreak in the San Francisco shelter (see Additional file 1 and Additional file 1: Table S3 for details), which is fully described elsewhere [5]. As of April 10, 2020, a total of 89 individuals (84 residents, 5 staff) of 175 tested (130 residents, 45 staff) in the shelter were PCR-positive. We obtained aggregate data from the outbreaks in the Boston and Seattle shelters, where identified COVID-19 cases triggered mass testing events $[4,6,7]$. In the Boston shelter, 147 of 408 residents and 15 of 50 staff were PCR-positive during testing conducted April 2-3, 2020. The numbers of residents and staff tested and positive in the three Seattle shelters (shelters $\mathrm{A}, \mathrm{B}$, and $\mathrm{C}$ ) at two testing events conducted March 30-April 1 and April 7-8, 2020, are given in Additional file 1: Table S4. For the San Francisco shelter, we used daily census data to inform the shelter population size, which decayed over time, and risk stratification for disease severity by age and comorbidity status (Additional file 1: Figure S2). For the other shelters, we assumed a constant population size over time.

\section{Model calibration}

We calibrated the model to the aggregate numbers of individuals PCR-positive out of those tested in each shelter (daily data for the San Francisco shelter, cross-sectional for the Seattle and Boston shelters) using approximate 
Bayesian computation techniques (see Additional file 1). We fitted the following parameters: (i) the basic reproduction number $R_{0}$ (the average number of secondary infections generated by the average infectious individual in an entirely susceptible shelter population), (ii) the number of latently infected individuals who initially entered the shelter $E_{0}$, and (iii) the number of days before the first case was identified that these individuals entered the shelter $D$ (Table 1 ). The remaining parameters were sourced from the literature on natural history and epidemiology of SARS-CoV-2 (Table 1 and Additional file 1: Table S5).

\section{Infection control strategies}

We simulated six infection control strategies (Additional file 1: Table S6), selected via informal consultation with public health experts. (1) Daily symptom-based screening: daily screening of all individuals in the shelter involving a temperature and symptom survey. Individuals who screened positive were PCR tested, with $80 \%$ compliance, and isolated for 1 day pending the test result; if negative, they returned to the population. We assumed that isolated individuals were unable to transmit or become infected. We used published data on the sensitivity of symptom-based screening with time since infection [72], which suggests that close to $100 \%$ of symptomatic cases (a subset of all true cases) would eventually be detected under repeated daily screening based on the definition of being symptomatic, even with low sensitivity of symptom screening on any one occasion (here assumed to be $40 \%$ to give a $98 \%$ probability of detection after 8 days of daily symptom screening). We assumed symptom screening had a daily specificity of $90 \%$, but assumed independence between screenings, meaning the overall specificity over the simulation was much lower and aligned with published estimates [76-78]. We assumed a minimum of 3 days between repeat PCR tests for the same individual based on typical clinical practice and test turnaround times. (2) Routine PCR testing: twice-weekly PCR testing of residents and staff based on prior literature analyzing reduction in transmission and cost-effectiveness under different testing frequencies [73-75]. We assumed 75\% sensitivity and 100\% specificity of PCR testing based on published literature [2831], a mean duration of detectable viral load (starting prior to development of symptoms) of 20 days (Additional file 1: Figure S3) [17, 20-24], and 80\% compliance with testing. We assumed test results were returned in 1 day, after which time individuals who tested PCR-positive were removed from the shelter population. (3) Universal mask wearing: wearing of masks by individuals within the shelter. We assumed that mask wearing reduced the amount of infectious SARS-CoV-2 material breathed into the air by infected individuals by $30 \%$ and that inhaled by susceptible individuals by $40 \%$ based on a review of the literature on filtration efficiencies of masks and the impact of mask wearing on infection risk (see Additional file 1), and that $60 \%$ of individuals adhered to mask wearing [37, 48]. (4) Relocation of "high-risk" individuals: moving high-risk individuals (defined as those $\geq 60$ years and/or with comorbidities) to single hotel rooms, modeled by replacing such individuals with lower-risk individuals. (5) Routine PCR testing of staff only: twice-weekly testing of staff only, assuming $80 \%$ compliance. (6) Combination strategy: strategies 1-4 combined. Daily symptom screening (strategy 1) was included in all strategies as it is considered a minimum requirement under $\mathrm{CDC}$ guidelines for control practices in homeless shelters [79].

\section{Prediction of impact of infection control strategies}

For each intervention strategy, we simulated transmission within a shelter of 250 residents and 50 staff (based on an average shelter size) over 30 days starting with one latently infected individual 1000 times (to account for stochastic uncertainty). The time period was chosen to capture the trajectory of an outbreak and the differential benefits of strategies. The primary outcome was the probability of averting an outbreak (defined as 3 or more infections originating within the shelter in any 14-day period $[80,81])$ under each strategy, with secondary outcomes of the proportional reductions in the total numbers of SARS-CoV-2 infections and clinical cases, and total numbers of hospitalizations, deaths and PCR tests used. Only individuals who tested positive were removed from the shelter population. The initial population was chosen to have the same composition in terms of proportions in different risk groups (by age and comorbidity status) as the San Francisco shelter. We estimated the probability of averting an outbreak under each intervention strategy (compared with no interventions) for each calibrated $R_{0}$ value for a range of different background infection rates estimated from incidence of confirmed cases in Seattle, Boston, and San Francisco (see Additional file 1 for details). To account for potential upward bias in the estimated $R_{0}$ range due to fitting to data from shelters with high attack rates, we performed the same simulations for a shelter environment with a low $R_{0}$ of 1.5 . The analyses were conducted in $\mathrm{R}$ version 4.0.0 [82], and the data and model code are available at https://github.com/LloydChapman/COVID_ homeless_modelling.

\section{Sensitivity analysis}

We conducted a multi-way sensitivity analysis to assess the impact of uncertainty in key natural history and intervention parameters-relative infectiousness of subclinical infection and the early infectious stage, 
Table 1 Microsimulation input parameters based on observed outbreak data from homeless shelters in Seattle, Boston, and San Francisco

\begin{tabular}{|c|c|c|c|}
\hline Parameter* & Base case value & $\begin{array}{l}\text { Range in sensitivity } \\
\text { analysis }^{\dagger}\end{array}$ & References \\
\hline \multicolumn{4}{|l|}{ Natural history } \\
\hline Mean duration of latent infection period, days & 3 days & - & [17] \\
\hline Mean duration of early infectious stage (subclinical/clinical), days & 2.3 days & - & [17] \\
\hline Mean duration of late infectious stage (subclinical/clinical), days & 8 days & - & {$[17,20,67,68]$} \\
\hline Relative infectiousness of subclinical infection to clinical infection & 1 & $0.5-1$ & {$[19,69,70]$} \\
\hline Relative infectiousness of early infectious stage to late infectious stage & 2 & $1-3$ & {$[17,18]$} \\
\hline Probability of developing clinical symptoms & $\begin{array}{l}\text { Age-dependent (see } \\
\text { Additional file 1: Table S2) }\end{array}$ & - & [13] \\
\hline Background infection rate in community outside shelter & $\begin{array}{l}\text { Shelter-specific (see } \\
\text { Additional file 1) }\end{array}$ & $\begin{array}{l}0-439 \text { infections } / 1,000,000 \\
\text { person-days }\end{array}$ & [49-51] \\
\hline Basic reproduction number, $R_{0}$ & Variable & $1.5-6.2$ & Estimated \\
\hline \multicolumn{4}{|l|}{ Intervention } \\
\hline \multicolumn{4}{|l|}{ Symptom screening } \\
\hline Sensitivity & 0.4 & $0.3-0.5$ & $\begin{array}{l}\text { Assumed based } \\
\text { on [72] }\end{array}$ \\
\hline Specificity & 0.9 & $0.8-0.9$ & Assumed \\
\hline Compliance of symptomatic individuals with PCR testing & $80 \%$ & $50-100 \%$ & Assumed \\
\hline \multicolumn{4}{|l|}{ PCR testing } \\
\hline Sensitivity & 0.75 & $0.6-0.9$ & [28-31] \\
\hline Specificity & 1 & $0.95-1$ & {$[28,31]$} \\
\hline Frequency & Twice weekly & Daily-monthly & [73-75] \\
\hline Compliance & $80 \%$ & $50-100 \%$ & Assumed \\
\hline \multicolumn{4}{|l|}{ Masks } \\
\hline Effectiveness at reducing infectious material exhaled & $30 \%$ & $10-50 \%$ & {$[36,37,42]^{\ddagger}$} \\
\hline Effectiveness at reducing infectious material inhaled & $40 \%$ & $20-60 \%$ & {$[36,37,42]^{\ddagger}$} \\
\hline Compliance & $60 \%$ & $30-100 \%$ & {$[37,48]$} \\
\hline
\end{tabular}

* See Additional file 1: Table S5 for a complete list of all parameters used in the model calibration and intervention simulations

${ }^{\dagger}$ In the sensitivity analysis, each intervention strategy was simulated with all combinations of the minimum and maximum values of the ranges for the indicated parameters to generate the uncertainty ranges around the probability of averting an outbreak in Table 2

${ }^{\ddagger}$ See Additional file 1 for a review of current literature on mask effectiveness and a full list of references

sensitivities and specificities of symptom screening and PCR tests, testing and masking compliances, and mask effectiveness-on the results, by simulating each intervention strategy across all combinations of the minimum and maximum values of these parameters over their uncertainty ranges (Table 1 ). We explored the impact of PCR testing frequency on the probability of averting an outbreak by varying the testing frequency in strategy 2 from daily to monthly.

\section{Results}

\section{Model calibration}

The model reproduced the numbers of PCR-positive individuals in the cross-sectional surveys in the Seattle and
Boston shelters (Additional file 1: Figure S4) and the observed numbers of PCR-positive individuals and symptomatic cases over time for the outbreak in the San Francisco shelter (Additional file 1: Figures S4-S5). The estimated $R_{0}$ values ranged from 2.9 (95\% CI 1.1-6.7) for Seattle shelter B to 6.2 (95\% CI 4.0-7.9) for the San Francisco shelter (Additional file 1: Table S7), with corresponding estimated cumulative infection incidences at the end of the testing period of $14 \%$ (95\% CI $1-41 \%$ ) and $83 \%$ (95\% CI 72-92\%) (Additional file 1: Table S8). The median estimated number of infections initially introduced was 3 for all shelters (95\% CI 1-5), but with a relatively flat posterior distribution extending to the bounds of the uniform prior distribution, reflecting considerable uncertainty in this parameter (Additional File 
1: Figure S10). The estimated date of introduction of infection ranged from 10 days (95\% CI 7-14 days) before the first case was identified for Seattle shelter B to 21 days (95\% CI 17-26 days) before for San Francisco.

\section{Impact of infection control strategies}

Table 2 shows the projected impact of the six infection control strategies considered, for different transmission environments. Daily symptom screening performed poorly for all levels of transmission (probability of averting an outbreak $=0.04$ for San Francisco $R_{0}=6.2$, and probability $=$ 0.35 for $R_{0}=1.5$ ). Relocating individuals at high-risk of clinical symptoms combined with symptom screening performed similarly to symptom screening alone (probability of averting an outbreak $=0.04-0.33$ for $R_{0}=6.2-1.5$ ). Twice-weekly PCR testing of staff provided some additional benefit over daily symptom screening at lower levels of transmission (probability of averting an outbreak $=0.04$ 0.41 for $R_{0}=6.2-1.5$ ). Twice-weekly PCR testing of all individuals and universal masking yielded higher probabilities of averting an outbreak of $0.09-0.53$ and $0.08-0.62$ for $R_{0}=6.2-1.5$, respectively. The combination strategy involving daily symptom screening, twice-weekly PCR testing of all individuals, universal masking, and removal of high-risk individuals gave the highest probability of averting an outbreak (0.19-0.74 for $\left.R_{0}=6.2-1.5\right)$, but still prevented a minority of outbreaks in all but the lowest-risk setting.

The probability of averting an outbreak under each intervention strategy decreased with increasing transmission potential $\left(R_{0}\right)$ inside the shelter and with increasing infection incidence in the community outside the shelter (Fig. 1). Even under the combination strategy, the probability of averting an outbreak in an averagetransmission-potential shelter $\left(R_{0}=2.9\right)$ decreased from 0.77 to 0.12 as the background infection rate increased from 0 to 439 cases per 1 million person-days (the estimated background infection rate in San Francisco between June 27 and July 10, 2020).

The relative reduction in infection incidence under the different infection control strategies followed the same pattern as the probability of averting an outbreak (Additional file 1: Table S10 and Fig. 2).

PCR test requirements were approximately three times higher (at an average of 6.6 tests per person per month) under twice-weekly PCR testing of all individuals than when only testing individuals identified as symptomatic in daily symptom screening (2.0 tests/person/month) and approximately two times higher than when only testing staff twice-a-week (2.8 tests/person/month) (Additional file 1: Table S11).

\section{Sensitivity analysis}

The probability of averting an outbreak was most sensitive to uncertainty in masking compliance and effectiveness and relative infectiousness of the early infectious stage, with the mean probability of averting an outbreak under combined interventions across all combinations of the minimum and maximum values of the other parameters varying from $0.40-0.71$ for $30-100 \%$ masking compliance, $0.49-0.62$ and $0.48-0.63$ for $10-50 \%$ and $20-$ $60 \%$ mask exhalation and inhalation effectiveness, and 0.63-0.48 for early-stage relative infectiousness of 1-3 for $R_{0}=2.9$ (Additional file 1: Figure S9). After this, the probability of averting an outbreak was most sensitive to PCR sensitivity and testing compliance, with the mean probability of averting an outbreak under combined interventions varying from $0.50-0.61$ and $0.51-0.60$ over the uncertainty ranges of these parameters. Decreasing the frequency of PCR testing from daily to monthly decreased the probability of averting an outbreak for $R_{0}=$ $1.5,2.9$, and 3.9 from 0.71 to $0.33,0.28$ to 0.12 , and 0.21 to 0.08 , respectively, but had little impact on the already

Table 2 Probability of averting an outbreak over a 30-day period in a generalized homeless shelter with simulated infection control strategies

\begin{tabular}{lllll}
\hline Infection control strategy $^{\ddagger}$ & \multicolumn{3}{l}{ Probability of averting an outbreak (UR) } \\
\cline { 2 - 5 } & $\boldsymbol{R}_{\mathbf{0}}=\mathbf{1 . 5}$ (low-risk) & $\boldsymbol{R}_{\mathbf{0}}=\mathbf{2 . 9}$ (Seattle) & $\boldsymbol{R}_{\mathbf{0}}=\mathbf{3 . 9}$ (Boston) & $\boldsymbol{R}_{\mathbf{0}}=\mathbf{6 . 2}$ (San Francisco) \\
\hline 1) Symptom screening & $0.35(0.21-0.67)$ & $0.13(0.05-0.39)$ & $0.08(0.02-0.28)$ & $0.04(0.00-0.15)$ \\
2) Routine twice-weekly PCR testing & $0.53(0.34-0.87)$ & $0.20(0.10-0.64)$ & $0.12(0.05-0.50)$ & $0.09(0.01-0.33)$ \\
3) Universal mask wearing & $0.62(0.26-0.99)$ & $0.27(0.07-0.94)$ & $0.19(0.04-0.90)$ & $0.08(0.01-0.77)$ \\
4) Relocation of high-risk individuals & $0.33(0.20-0.68)$ & $0.13(0.05-0.40)$ & $0.07(0.02-0.29)$ & $0.04(0.00-0.15)$ \\
5) Routine twice-weekly PCR testing of staff only & $0.41(0.28-0.72)$ & $0.15(0.07-0.40)$ & $0.09(0.03-0.33)$ & $0.04(0.01-0.17)$ \\
6) Combination strategy & $0.74(0.40-1)$ & $0.42(0.13-0.99)$ & $0.29(0.07-0.97)$ & $0.19(0.02-0.91)$ \\
\hline
\end{tabular}

Outbreak is defined as $\geq 3$ infections originating within the shelter in any 14-day period

Generalized homeless shelter defined as 250 residents and 50 staff with a background infection rate estimated from data for Boston ( 120/1,000,000 person-days)

See Additional file 1: Table S9 and Fig. 1 for the results for other background infection rates and Additional file 1: Table S10 for the reductions in infections and symptomatic cases. See Additional file 1: Figures S6-S8 for the outbreak size distributions for the different $R_{0}$ values

$U R$ uncertainty range, $R_{0}$ basic reproduction number

${ }^{\ddagger}$ All strategies included daily symptom screening

${ }^{\S}$ UR generated from parameter sensitivity analysis (see Table 1 and Additional file 1) 


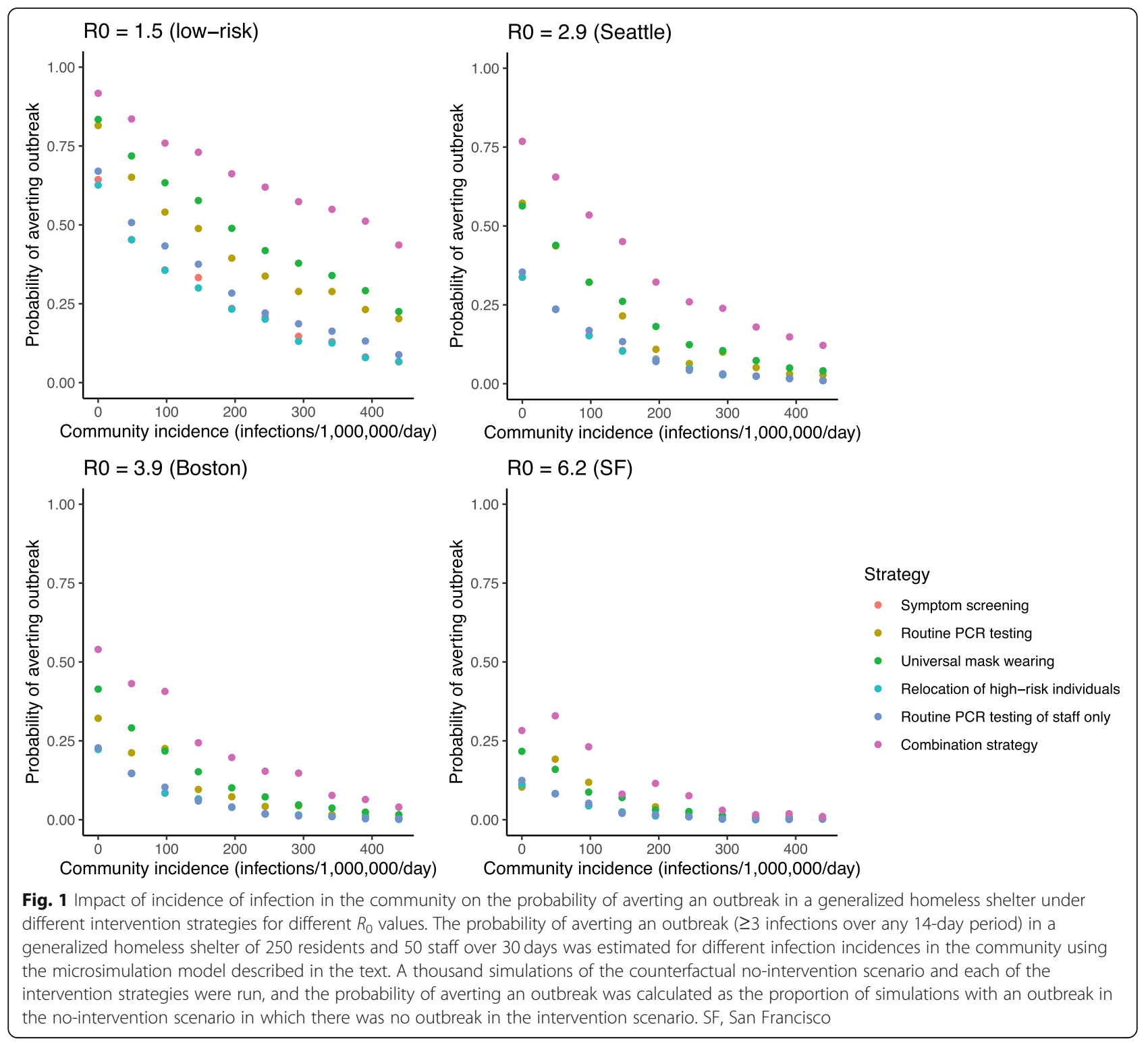

low probability of averting an outbreak for $R_{0}=6.2$ (Fig. 3).

\section{Discussion}

Several outbreaks of COVID-19 with high attack rates have occurred in homeless shelters across the US, and there remains uncertainty over the best infection control strategies to reduce outbreak risk in shelters. In this study, we applied a simulation analysis to identify infection control strategies to prevent future outbreaks. We found that in high-risk shelters that are unable to maximize basic infection control practices that sufficiently reduce the transmissibility of SARS-CoV-2 (e.g., social distancing, reduced living density), no additional infection control strategy is likely to prevent outbreaks. Similarly, in cities with high community incidence, no infection control practices are likely to prevent an outbreak. In contrast, in lower-risk shelters with low background community incidence, the implementation of strategies such as symptom screening, routine PCR testing, and masking would help reduce outbreak risk.

We found a wide range of transmissibility of SARSCoV-2 based on observed outbreaks in homeless shelters, which greatly affects intervention impact. We estimated basic reproduction numbers $\left(R_{0}\right)$ of 2.9-6.2 from aggregate PCR test data from outbreaks in five shelters in Seattle, Boston, and San Francisco between March and April 2020. This range of $R_{0}$ values is at the high end of estimates reported in the literature $[52,63,83,84]$ and likely reflects a high degree of heterogeneity in infectiousness between individuals [62-66] and a highly conducive environment for transmission within these shelters early 


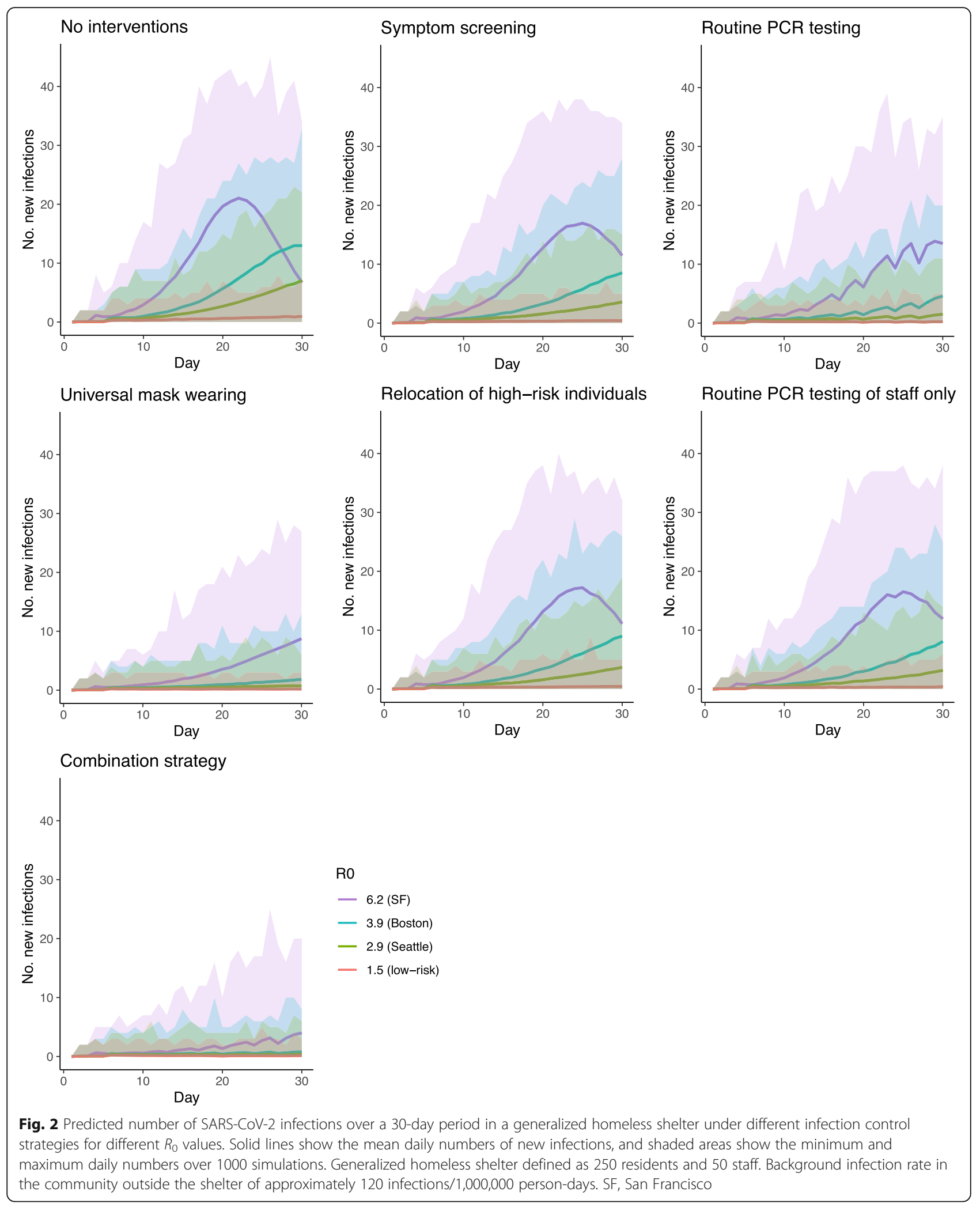




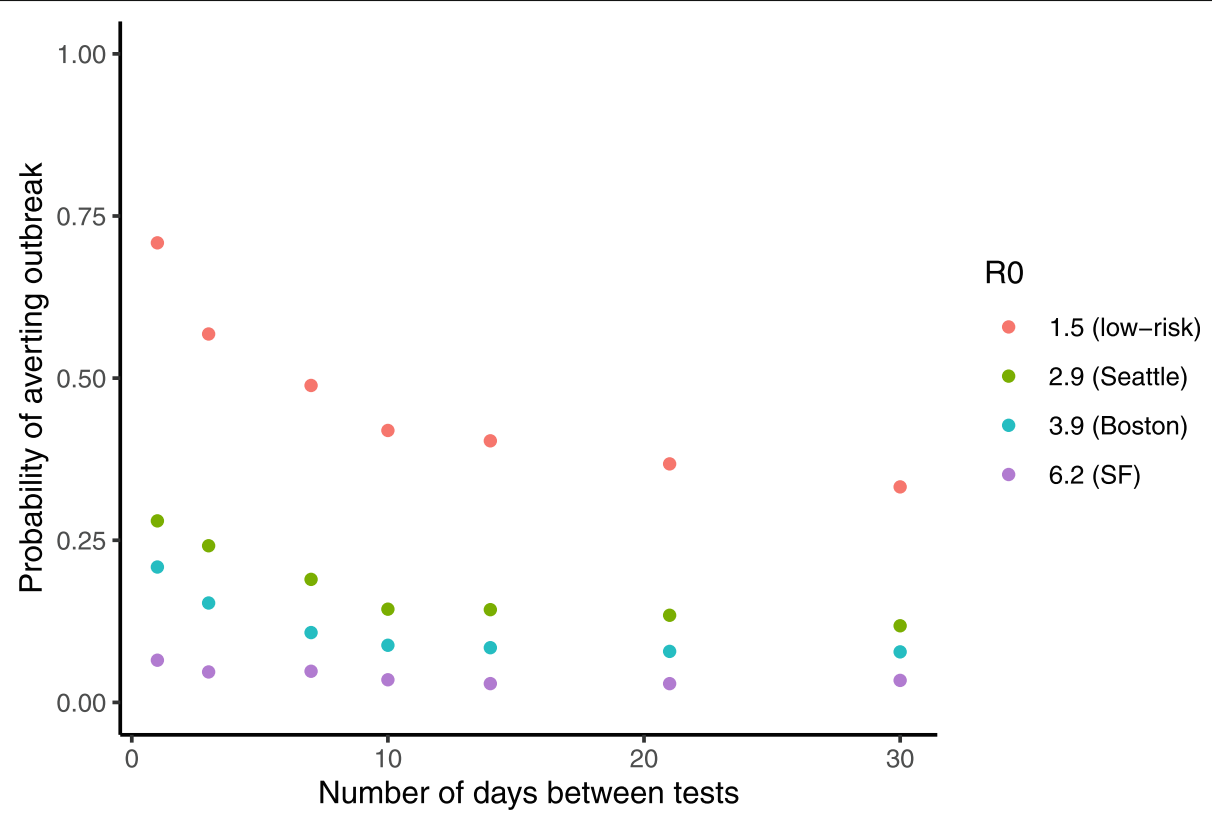

Fig. 3 Impact of varying the frequency of routine PCR testing of residents and staff on the probability of averting an outbreak in a generalized homeless shelter for different $R_{0}$ values. The probability of averting an outbreak ( $\geq 3$ infections over any 14-day period) over 30 days was estimated for different frequencies of routine PCR testing from daily (1 day between tests) to monthly (30 days between tests). Generalized homeless shelter defined as 250 residents and 50 staff. Background infection rate in the local community of approximately 120 infections/ 1,000,000 person-days. SF, San Francisco

in the pandemic due to lack of existing infection control practices and high living density at the time of the outbreaks. For these $R_{0}$ values and representative background infection rates, we found that the infection control strategies considered are unlikely to prevent outbreaks (probability $<50 \%$ ), even when combined. Nevertheless, they do reduce the incidence of infection and clinical disease and slow the growth of the outbreak (Fig. 2). Our $R_{0}$ estimates are likely not entirely representative of general transmission potential in shelters now given that the outbreaks occurred early during the pandemic when control measures were limited and that non-outbreaks and smaller outbreaks may go undetected or unreported. Control measures such as rehousing of individuals to single hotel rooms appear to have been successful, and incidence has in general been lower in the homeless population than anticipated [85]. However, there have been subsequent large outbreaks in homeless shelters despite reduced shelter density and stringent control efforts [86-88]. This supports our finding that outbreaks in congregate shelters remain likely even with fairly intensive infection control practices.

In lower transmissibility settings, e.g., with $R_{0}=1.5$, which may be more representative of typical shelters now due to improved social distancing and basic infection control practices, the intervention strategies we have considered are more likely to prevent outbreaks (probability up to nearly $75 \%$ under combined interventions, for a moderate background infection rate of approximately 120/1,000,000/day).

A key remaining issue given the limited availability of alternative housing for people experiencing homelessness is identifying the characteristics that distinguish low-risk shelters (those similar to the $R_{0}=1.5$ scenario considered here) that can be operated with low outbreak risk with implementation of infection control strategies. Data are limited, but available evidence suggests that social distancing and reductions in super-spreading are likely to be key factors $[62,63,89-91]$. Strategies that may achieve these goals include reducing living density, spacing bedding, reducing communal activities, and adopting staffing models that limit social contacts.

The fact that intervention impact and the probability of averting an outbreak decrease significantly with increasing background infection rate in the community (Fig. 1) suggests a need for alternative housing arrangements for people experiencing homelessness in locations in which community incidence is moderate to high $-100-500$ infections/1,000,000/day, equivalent to $25-125$ confirmed cases/1,000,000/day assuming fourfold underreporting (see Additional file 1). In lower background incidence settings, combined daily symptom-based screening, twiceweekly PCR testing, universal masking, and relocation of high-risk individuals to non-congregate settings would reduce outbreak risk and limit the incidence of infection and severe disease if outbreaks do occur. 
Our findings broadly agree with those of two other modeling studies of interventions against COVID-19 in homeless shelters: one in the US [92] and the other in England [93]. The former found that a combination of daily symptom screening with PCR testing of symptompositive individuals, universal PCR testing every 2 weeks, and alternative care sites for those with mild/moderate COVID-19 would significantly reduce infections, while remaining cost-effective, but unlike our analysis did not consider variation in the effectiveness of interventions with community incidence. The latter study supports our results on the high risk of outbreaks in congregate homeless shelters, as it found that outbreaks in homeless shelters are likely even when incidence in the general population is low and estimated that closure of congregate shelters during the first pandemic wave in England averted over $90 \%$ of infections that would have otherwise occurred in the homeless population.

Each infection control strategy is limited in some aspect $[17,18,69,94-96]$. Symptom-based screening has very low sensitivity to detect infections early in the clinical course (when people are most infectious) and has poor specificity $[72,76,77,97]$. The impact of routine PCR testing is limited by imperfect PCR sensitivity ( $75 \%$ ), especially early in the infection course [28], as well as the need for frequent testing and missing onset of infectiousness between testing periods. Other analyses support our finding that testing less than once or twice weekly leaves a high risk of outbreaks (e.g., testing once every 2 weeks gives a 30\% lower probability of averting an outbreak than twice-weekly testing, Fig. 3) [73-75]. However, once- or twice-weekly testing may be financially and logistically infeasible. Similarly, relocation of high-risk persons to independent housing is resourceintensive. Frequent testing and universal masking also suffer issues with adherence and may not be possible for all individuals at all times in homeless shelters.

This study has a number of limitations. Due to limited data availability, we only calibrated the model to a small number of shelter outbreaks, the $R_{0}$ estimates for which are likely to be higher than for the average shelter since they occurred early in the pandemic and larger outbreaks are more likely to be reported. The crosssectional aggregate nature of the majority of the data also led to wide uncertainty intervals around the fitted parameters, without independent identifiability between them (Additional file 1: Figure S10). Our results suggest that universal masking would significantly reduce the risk of outbreaks in homeless shelters, even with $60 \%$ compliance. However, the impact of masking is highly sensitive to the assumed masking effectiveness and compliance, estimates for which still vary considerably despite accumulating evidence that masks reduce infection risk [36, 37, 39, 98, 99]. Many uncertainties in the biology of SARS-CoV-2 transmission remain, particularly regarding differential infectiousness over time and by the severity of illness, and the relationship of PCR positivity and infectiousness [17, 19, 67]. Our assumption of equal infectiousness for different individuals means that our model is unlikely to fully reproduce super-spreading events $[62,63]$. We made several simplifying assumptions in modeling transmission within the shelter and from the surrounding community, namely, homogenous mixing within the shelter population, no entry of new people, a stable background infection rate over time, and full immunity upon recovery from infection given the short duration of the simulation. Our assumption that individuals who are isolated within homeless shelters while awaiting test results are unable to transmit or become infected may have led to a slight overestimation of the impact of testing, since in reality isolation is not perfect. We assumed homogeneous mixing due to a lack of contact data for the shelter outbreaks, which meant that we were not able to consider cohorting and contact tracing as interventions.

\section{Conclusions}

This study defines conditions for operating homeless shelters with a lower risk of COVID-19 outbreaks and estimates the impact of various interventions on outbreak risk. Our findings demonstrate the need for combined interventions (symptom-based screening, PCR testing, and masking) and regular testing to protect persons experiencing homelessness from COVID-19, while highlighting the limitations of these interventions in preventing outbreaks.

\section{Abbreviations}

Cl: Credible interval; COVID-19: Coronavirus disease 2019; PCR: Polymerase chain reaction; SARS-CoV-2: Severe acute respiratory syndrome coronavirus 2; UR: Uncertainty range; US: United States

\section{Supplementary Information}

Supplementary information accompanies this paper at https://doi.org/10. 1186/s12916-021-01965-y.

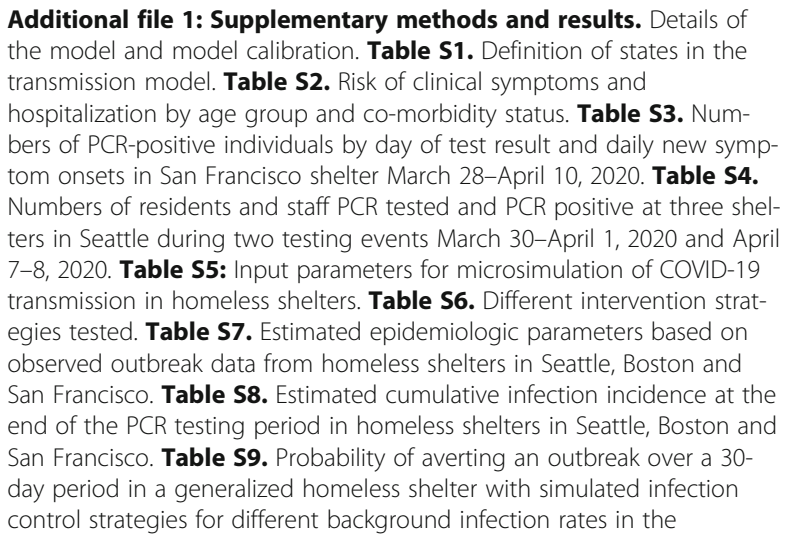


community outside the shelter. Table S10. Reductions in the total number of infections and symptomatic cases over a 30-day period in a generalized homeless shelter with simulated infection control strategies for different background infection rates in the community outside the shelter. Table S11. Numbers of PCR tests used under each infection control strategy. Figure S1. Structure of stochastic individual-level susceptibleexposed-infectious-recovered (S-E-I-R) model of COVID-19 transmission in homeless shelter. Figure S2. Daily numbers of residents by risk group present in the San Francisco shelter March 29-April 10, 2020. Figure S3. Distribution of duration of detectable viral load from start of late infectious stage. Figure S4. Calibration of microsimulation to observed PCR testing data from outbreaks in homeless shelters in Seattle, Boston and San Francisco. Figure S5. Calibration of microsimulation to additional data from San Francisco shelter outbreak. Figure S6. Outbreak size distributions 30 days after introduction of infection in a generalized homeless shelter under different infection control strategies for $R_{0}=1.5$ (low-risk setting). Figure S7. Outbreak size distributions 30 days after introduction of infection in a generalized homeless shelter under different infection control strategies for $R_{0}=2.9$ (Seattle). Figure S8. Outbreak size distributions 30 days after introduction of infection in a generalized homeless shelter under different infection control strategies for $R_{0}=6.2$ (San Francisco). Figure S9. Spider diagrams showing the sensitivity of the estimated probability of averting an outbreak to variation in key natural history and intervention parameters for different $R_{0}$ values. Figure $\mathbf{S 1 0}$. Posterior distributions and pairwise correlation plots for calibrated model parameters $-R_{0}, E_{0}$ and $T-$ for $(A)-(C)$ Seattle shelters $A-C$, (D) Boston shelter and (E) San Francisco shelter.

\section{Acknowledgements}

We sincerely appreciate the hard work and public health efforts of all those involved in the collection of the data used in this article. LACC would like to thank Renata Retkute, Amanda Minter, Simon Spencer, and TJ McKinley for helpful discussions regarding approximate Bayesian computation.

\section{Authors' contributions}

NCL and MK conceived the study. LACC and NCL designed and conducted the analysis and drafted the manuscript. SNC, AS, CC, TN, and El acquired and curated the data from the San Francisco shelter outbreak. NCL and MK acquired funding. All authors contributed to, read, and approved the final manuscript. LACC and NCL had full access to all of the data in the study and take responsibility for the integrity of the data and the accuracy of the data analysis.

\section{Funding}

This work was supported by the UCSF Benioff Homelessness and Housing Initiative. NCL is supported by the University of California, San Francisco (Department of Medicine). The funders had no role in the study design, data collection and analysis, preparation of the manuscript, or the decision to submit the manuscript for publication.

\section{Availability of data and materials}

The datasets supporting the conclusions of this article are available in the GitHub repository, https://github.com/LloydChapman/COVID_homeless_ modelling

\section{Declarations}

\section{Ethics approval and consent to participate}

This study was considered exempt non-human subject research based on the use of de-identified secondary data by the University of California, San Francisco Institutional Review Board.

\section{Consent for publication}

Not applicable.

\section{Competing interests}

The authors declare that they have no competing interests. NCL has received funding from the World Health Organization for unrelated work.

\section{Author details}

Department of Medicine, University of California, San Francisco, San Francisco, CA 94110, USA. ²Center for Vulnerable Populations, Zuckerberg San Francisco General Hospital and Trauma Center, University of California, San Francisco, San Francisco, CA, USA. ${ }^{3}$ San Francisco Department of Public Health, San Francisco, CA, USA. ${ }^{4}$ Department of Emergency Medicine, University of California, San Francisco, San Francisco, CA, USA. ${ }^{5}$ Division of HIV, Infectious Diseases, and Global Medicine, University of California, San Francisco, San Francisco, CA, USA.

Received: 28 October 2020 Accepted: 18 March 2021

Published online: 07 May 2021

\section{References}

1. Henry M, Watt R, Mahathey A, Ouellette J, Sitler A, Associates A, et al. The 2019 Annual Homeless Assessment Report (AHAR) to Congress. DC: Washington; 2020

2. Perri M, Dosani N, Hwang SW. COVID-19 and people experiencing homelessness: challenges and mitigation strategies. CMAJ. 2020;192(26): E716-9. https://doi.org/10.1503/cmaj.200834

3. Culhane D, Treglia D, Steif K, Kuhn R, Byrne T. Estimated emergency and observational/quarantine capacity need for the US homeless population related to COVID-19 exposure by county; Projected Hospitalizations, Intensive Care Units and Mortality. 2020. https://works.bepress.com/dennis culhane/237/. Accessed 14 Apr 2020.

4. Mosites E, Parker EM, N Clarke KE, Gaeta JM, Baggett TP, Imbert E, et al. Assessment of SARS-CoV-2 infection prevalence in homeless shelters-four U.S. cities, March 27-April 15, 2020. Morb Mortal Wkly Rep. 2020;69. https:// doi.org/10.1101/2020.04.12.20059618v1

5. Imbert E, Kinley PM, Scarborough A, Cawley C, Sankaran M, Cox SN, Kushel M, Stoltey J, Cohen S, Fuchs JD. Coronavirus disease 2019 (COVID-19) outbreak in a San Francisco homeless shelter. Clin Infect Dis. 2020; https:// doi.org/10.1093/cid/ciaa1071.

6. Baggett TP, Keyes H, Sporn N, Gaeta JM. Prevalence of SARS-CoV-2 infection in residents of a large homeless shelter in Boston. J Am Med Assoc. 2020; 323(21):2191-2. https://doi.org/10.1001/jama.2020.6887.

7. Tobolowsky FA, Gonzales E. COVID-19 outbreak among three affiliated homeless service sites_-King County, Washington, 2020. Morb Mortal Wkly Rep. 2020:69(17):523-6. https://doi.org/10.15585/mmwr.mm6917e2.

8. Oran DP, Topol EJ. Prevalence of asymptomatic SARS-CoV-2 infection: a narrative review. Ann Intern Med. 2020;173(5):362-7. https://doi.org/10.7326/ M20-3012.

9. World Health Organization. Transmission of SARS-CoV-2: implications for infection prevention precautions. 2020. https://www.who.int/publications/i/ item/modes-of-transmission-of-virus-causing-covid-19-implications-for-ipcprecaution-recommendations. Accessed 11 Aug 2020.

10. Centers for Disease Control. Interim considerations for health departments for SARS-CoV-2 testing in homeless shelters and encampments. 2020. https://www.cdc.gov/coronavirus/2019-ncov/community/homeless-shelters/ testing.html. Accessed 11 Aug 2020.

11. Centers for Disease Control. Investigating and responding to COVID-19 cases at homeless service provider sites. 2020. https://www.cdc.gov/corona virus/2019-ncov/php/investigating-cases-homeless-shelters.html. Accessed 11 Aug 2020.

12. Bertozzi AL, Franco E, Mohler G, Short MB, Sledge D. The challenges of modeling and forecasting the spread of COVID-19. Proc Natl Acad Sci. 2020; 202006520

13. Davies NG, Klepac P, Liu Y, Prem K, Jit M, Eggo RM. Age-dependent effects in the transmission and control of COVID-19 epidemics. medRxiv. 2020;2020 03.24.20043018. https://doi.org/10.1101/2020.03.24.20043018.

14. Wang D, Hu B, Hu C, Zhu F, Liu X, Zhang J, Wang B, Xiang H, Cheng Z, Xiong Y, Zhao Y, Li Y, Wang X, Peng Z. Clinical characteristics of 138 hospitalized patients with 2019 novel coronavirus-infected pneumonia in Wuhan, China. J Am Med Assoc. 2020;323(11):1061-9. https://doi.org/10.1 001/jama.2020.1585.

15. Tuite AR, Fisman DN, Greer AL. Mathematical modelling of COVID-19 transmission and mitigation strategies in the population of Ontario, Canada. CMAJ. 2020;192(19):E497-505. https://doi.org/10.1503/cmaj.200476.

16. Yang $X, Y u$ Y, Xu J, Shu H, Xia J, Liu H, et al. Clinical course and outcomes of critically ill patients with SARS-CoV-2 pneumonia in Wuhan, China: a single- 
centered, retrospective, observational study. Lancet Respir Med. 2020;8(5): 475-81. https://doi.org/10.1016/S2213-2600(20)30079-5.

17. He X, Lau EHY, Wu P, Deng X, Wang J, Hao X, Lau YC, Wong JY, Guan Y, Tan X, Mo X, Chen Y, Liao B, Chen W, Hu F, Zhang Q, Zhong M, Wu Y, Zhao L, Zhang F, Cowling BJ, Li F, Leung GM. Temporal dynamics in viral shedding and transmissibility of COVID-19. Nat Med. 2020;26(5):672-5. https://doi.org/10.1038/s41591-020-0869-5.

18. Casey M, Griffin J, McAloon CG, Byrne AW, Madden JM, McEvoy D, et al. Estimating pre-symptomatic transmission of COVID-19: a secondary analysis using published data. medRxiv. 2020;:2020.05.08.20094870. https://doi.org/1 0.1101/2020.05.08.20094870.

19. Long QX, Tang XJ, Shi QL, Li Q, Deng HJ, Yuan J, Hu JL, Xu W, Zhang Y, Lv FJ, Su K, Zhang F, Gong J, Wu B, Liu XM, Li JJ, Qiu JF, Chen J, Huang AL. Clinical and immunological assessment of asymptomatic SARS-CoV-2 infections. Nat Med. 2020;26(8):1200-4. https://doi.org/10.1038/s41591-020-0965-6.

20. Wölfel R, Corman VM, Guggemos W, Seilmaier M, Zange S, Müller MA, Niemeyer D, Jones TC, Vollmar P, Rothe C, Hoelscher M, Bleicker T, Brünink S, Schneider J, Ehmann R, Zwirglmaier K, Drosten C, Wendtner C. Virological assessment of hospitalized patients with COVID-2019. Nature. 2020; 581(7809):465-9. https://doi.org/10.1038/s41586-020-2196-х.

21. To KKW, Tsang OTY, Leung WS, Tam AR, Wu TC, Lung DC, et al. Temporal profiles of viral load in posterior oropharyngeal saliva samples and serum antibody responses during infection by SARS-CoV-2: an observational cohort study. Lancet Infect Dis. 2020;20(5):565-74. https://doi.org/10.1016/ S1473-3099(20)30196-1.

22. Zhou F, Yu T, Du R, Fan G, Liu Y, Liu Z, et al. Clinical course and risk factors for mortality of adult inpatients with COVID-19 in Wuhan, China: a retrospective cohort study. Lancet. 2020;395(10229):1054-62. https://doi. org/10.1016/S0140-6736(20)30566-3.

23. Zou L, Ruan F, Huang M, Liang L, Huang H, Hong Z, Yu J, Kang M, Song Y, Xia J, Guo Q, Song T, He J, Yen HL, Peiris M, Wu J. SARS-CoV-2 viral load in upper respiratory specimens of infected patients. N Engl J Med. 2020; 382(12):1177-9. https://doi.org/10.1056/NEJMc2001737.

24. Xiao AT, Tong YX, Gao C, Zhu L, Zhang YJ, Zhang S. Dynamic profile of RTPCR findings from 301 COVID-19 patients in Wuhan, China: a descriptive study. J Clin Virol. 2020;127:0-6.

25. Zhou R, Li F, Chen F, Liu H, Zheng J, Lei C, Wu X. Viral dynamics in asymptomatic patients with COVID-19. Int J Infect Dis. 2020;96:288-90. https://doi.org/10.1016/j.ijid.2020.05.030.

26. Liu Y, Yan LM, Wan L, Xiang TX, Le A, Liu JM, et al. Viral dynamics in mild and severe cases of COVID-19. Lancet Infect Dis. 2020;20(6):656-7. https:// doi.org/10.1016/S1473-3099(20)30232-2.

27. Heald-Sargent T, Muller WJ, Zheng X, Rippe J, Patel AB, Kociolek LK. Agerelated differences in nasopharyngeal severe acute respiratory syndrome coronavirus 2 (SARS-CoV-2) levels in patients with mild to moderate coronavirus disease 2019 (COVID-19). JAMA Pediatr. 2020;174(9):902-3. https://doi.org/10.1001/jamapediatrics.2020.3651

28. Kucirka LM, Lauer SA, Laeyendecker O, Boon D, Lessler J. Variation in falsenegative rate of reverse transcriptase polymerase chain reaction-based SARS-CoV-2 tests by time since exposure. Ann Intern Med. 2020;173(4):2627. https://doi.org/10.7326/M20-1495

29. Arevalo-Rodriguez I, Buitrago-Garcia D, Simancas-Racines D, ZambranoAchig P, Campo R Del, Ciapponi A, et al. False-negative results of initial RTPCR assays for COVID-19: a systematic review. PLoS One. 2020;15 12:1-19.

30. Watson J, Whiting PF, Brush JE. Interpreting a covid-19 test result. BMJ. 2020;369:1-7. https://doi.org/10.1136/bmj.m1808.

31. Padhye NS. Reconstructed diagnostic sensitivity and specificity of the RTPCR test for COVID-19. medRxiv. 2020;:2020.04.24.20078949. https://doi.org/1 0.1101/2020.04.24.20078949.

32. Chu DK, Akl EA, Duda S, Solo K, Yaacoub S, Schünemann HJ, Chu DK, Akl EA, elharakeh A, Bognanni A, Lotfi T, Loeb M, Hajizadeh A, Bak A, Izcovich A, Cuello-Garcia CA, Chen C, Harris DJ, Borowiack E, Chamseddine F, Schünemann F, Morgano GP, Muti Schünemann GEU, Chen G, Zhao H, Neumann I, Chan J, Khabsa J, Hneiny L, Harrison L, Smith M, Rizk N, Giorgi Rossi P, AbiHanna P, el-khoury R, Stalteri R, Baldeh T, Piggott T, Zhang Y, Saad Z, Khamis A, Reinap M, Duda S, Solo K, Yaacoub S, Schünemann HJ. Physical distancing, face masks, and eye protection to prevent person-to-person transmission of SARS-CoV-2 and COVD-19: a systematic review and meta-analysis. Lancet. 2020;395(10242):1973-87. https:/doi.org/10.1016/S01406736(20)31142-9.

33. Liang M, Gao L, Cheng C, Zhou Q, Uy JP, Heiner K, et al. Efficacy of face mask in preventing respiratory virus transmission: a systematic review and meta-analysis. Travel Med Infect Dis. 2020:101751. https://doi.org/10.1016/j. tmaid.2020.101751.

34. Li Y, Liang M, Gao L, Ayaz Ahmed M, Uy JP, Cheng C, Zhou Q, Sun C. Face masks to prevent transmission of COVID-19: a systematic review and metaanalysis. Am J Infect Control. 2020;000 https://doi.org/10.1016/j.ajic.2020.12.007.

35. Coclite D, Napoletano A, Gianola S, del Monaco A, D'Angelo D, Fauci A, et al. Face mask use in the community for reducing the spread of COVID19: a systematic review. Front Med. 2021;7:1060. https://doi.org/10.3389/ fmed.2020.594269.

36. Brainard J, Jones NR, Lake IR, Hooper L, Hunter PR. Community use of face masks and similar barriers to prevent respiratory illness such as COVID-19: a rapid scoping review. Eurosurveillance. 2020;25(49) https://doi.org/10.2807/1 560-7917.ES.2020.25.49.2000725.

37. Gakidou E, Pigott DM, Troeger CE, Hulland EN, Jr RCR, Adolph C, et al. Global projections of lives saved from COVID-19 with universal mask use. medRxiv. 2020;2020.10.08.20209510. https://doi.org/10.1101/2020.10.08.202 09510.

38. Chou R, Dana T, Jungbauer R, Weeks C, McDonagh MS. Masks for prevention of respiratory virus infections, including SARS-CoV-2, in health care and community settings: a living rapid review. Ann Intern Med. 2020; 173(7):542-55. https://doi.org/10.7326/M20-3213.

39. Howard J, Huang A, Li Z, Tufekci Z, Zdimal V, van der Westhuizen H-M, von Delft A, Price A, Fridman L, Tang LH, Tang V, Watson GL, Bax CE, Shaikh R, Questier F, Hernandez D, Chu LF, Ramirez CM, Rimoin AW. An evidence review of face masks against COVID-19. Proc Natl Acad Sci. 2021;118(4): e2014564118. https://doi.org/10.1073/pnas.2014564118.

40. Wang $Y$, Tian H, Zhang L, Zhang M, Guo D, Wu W, et al. Reduction of secondary transmission of SARS-CoV-2 in households by face mask use, disinfection and social distancing: a cohort study in Beijing, China. BMJ Glob Heal. 2020;5:1-9.

41. Doung-Ngern $P$, Suphanchaimat R, Panjangampatthana A, Janekrongtham C, Ruampoom D, Daochaeng N, et al. Case-control study of use of personal protective measures and risk for SARS-CoV 2 infection, Thailand. Emerg Infect Dis. 2020;26(11):2607-16. https://doi.org/10.3201/eid2611.203003.

42. Mueller A, Eden M, Oakes J, Bellini C, Fernandez L. Quantitative method for comparative assessment of particle removal efficiency of fabric masks as alternatives to standard surgical masks for PPE. Matter. 2020;3(3):950-62. https://doi.org/10.1016/j.matt.2020.07.006.

43. Konda A, Prakash A, Moss GA, Schmoldt M, Grant GD, Guha S. Aerosol filtration efficiency of common fabrics used in respiratory cloth masks. ACS Nano. 2020;14(5):6339-47. https://doi.org/10.1021/acsnano.0c03252.

44. Aydin O, Emon B, Cheng S, Hong L, Chamorro LP, Saif MTA. Performance of fabrics for home-made masks against the spread of COVID-19 through droplets: a quantitative mechanistic study. Extrem Mech Lett. 2020;40: 100924. https://doi.org/10.1016/j.eml.2020.100924.

45. Clase CM, Fu EL, Ashur A, Beale RCL, Clase IA, Dolovich MB, Jardine MJ, Joseph M, Kansiime G, Mann JFE, Pecoits-Filho R, Winkelmayer WC, Carrero JJ. Forgotten technology in the COVID-19 pandemic: filtration properties of cloth and cloth masks - a narrative review. Mayo Clin Proc. 2020;95(10): 2204-24. https://doi.org/10.1016/j.mayocp.2020.07.020.

46. Sickbert-Bennett EE, Samet JM, Clapp PW, Chen H, Berntsen J, Zeman KL, Tong $H$, Weber DJ, Bennett WD. Filtration efficiency of hospital face mask alternatives available for use during the COVID-19 pandemic. JAMA Intern Med. 2020;180(12):1607-12. https://doi.org/10.1001/jamainternmed.2020.4221.

47. Bundgaard $\mathrm{H}$, Bundgaard JS, Raaschou-Pedersen DET, von Buchwald C, Todsen T, Norsk JB, et al. Effectiveness of adding a mask recommendation to other public health measures to prevent SARS-CoV-2 infection in Danish mask wearers. Ann Intern Med. 2020;174(3):335-43. https://doi.org/10.7326/M20-6817.

48. Rader B, White LF, Burns MR, Chen J, Brilliant J, Cohen J, et al. Mask wearing and control of SARS-CoV-2 transmission in the United States Benjamin. medRxiv. 2020;:2020.08.23.20078964; https://doi.org/10.1101/2020.08.23.2 0078964.

49. King County Department of Public Health. Daily COVID-19 outbreak summary - King County. 2020. https://www.kingcounty.gov/depts/health/ covid-19/data/daily-summary.aspx. Accessed 13 Aug 2020.

50. City of Boston. COVID-19 case tracker. 2020. https://dashboard.cityofboston. gov/t/Guest_Access_Enabled/views/COVID-19/Dashboard1?:showAppBa nner=false\&:display_count=n\&:showVizHome=n\&:origin=viz_share_link\&: isGuestRedirectFromVizportal=y\&:embed=y. Accessed 13 Aug 2020.

51. San Francisco Department of Public Health. COVID-19 cases summarized by date, transmission and case disposition - city and county of San Francisco. 
2020. https://data.sfgov.org/COVID-19/COVID-19-Cases-Summarized-by-DateTransmission-and/tvq9-ec9w. Accessed 13 Aug 2020.

52. MIDAS Network. COVID-19 parameter estimates. https://github.com/midasnetwork/COVID-19/tree/master/parameter_estimates/2019_novel_corona virus. Accessed 11 Aug 2020.

53. Abbott S, Hellewell J, Thompson RN, Sherratt K, Gibbs HP, Bosse NI, Munday JD, Meakin S, Doughty EL, Chun JY, Chan YWD, Finger F, Campbell P, Endo A, Pearson CAB, Gimma A, Russell T, CMMID COVID modelling group, Flasche S, Kucharski AJ, Eggo RM, Funk S. Estimating the time-varying reproduction number of SARS-CoV-2 using national and subnational case counts. Wellcome Open Res. 2020;5:112. https://doi.org/10.12688/ wellcomeopenres. 16006.2 .

54. U.S. Census Bureau. U.S. Census Bureau QuickFacts. 2020. https://www. census.gov/quickfacts/fact/table/seattlecitywa shington,bostoncitymassachusetts,sanfranciscocitycalifornia/PST045219. Accessed 1 Sept 2020.

55. Havers FP, Reed C, Lim T, Montgomery JM, Klena JD, Hall AJ, et al. Seroprevalence of antibodies to SARS-CoV-2 in 10 sites in the United States, March 23-May 12, 2020. JAMA Intern Med. 2020;30329:1-11.

56. Centers for Disease Control. Interactive Serology Dashboard for Commercial Laboratory Surveys. 2020. https://www.cdc.gov/coronavirus/2019-ncov/ca ses-updates/commercial-labs-interactive-serology-dashboard.html. Accessed 21 Aug 2020.

57. Andrews D, Salcedo F, Donahue L, Urwiler M, Simmonds M, Barber E, et al. Seattle/King County point-in-time count of persons experiencing homelessness. 2019. www.allhomekc.orgwww.appliedsurveyresearch.org. Accessed 20 Aug 2020

58. King County Department of Public Health. Homelessness and COVID-19. 2020. https://www.kingcounty.gov/depts/health/covid-19/data/homeless.a spx. Accessed 21 Aug 2020.

59. Minter A, Retkute R. Approximate Bayesian computation for infectious disease modelling. Epidemics. 2019;29 February:100368. https://doi.org/10.1 016/j.epidem.2019.100368.

60. Toni T, Welch D, Strelkowa N, Ipsen A, Stumpf MPH. Approximate Bayesian computation scheme for parameter inference and model selection in dynamical systems. J R Soc Interface. 2009:6(31):187-202. https://doi.org/1 0.1098/rsif.2008.0172.

61. Toni T, Stumpf MPH. Simulation-based model selection for dynamical systems in systems and population biology. Bioinformatics. 2009;26:104-10.

62. Lau MSY, Grenfell B, Thomas M, Bryan M, Nelson K, Lopman B. Characterizing superspreading events and age-specific infectiousness of SARS-CoV-2 transmission in Georgia, USA. Proc Natl Acad Sci. 2020;117: 202011802.

63. Endo A, Abbott S, Kucharski AJ, Funk S. Estimating the overdispersion in COVID-19 transmission using outbreak sizes outside China. Wellcome Open Res. 2020;5:1-13.

64. James A, Eagle L, Phillips C, Hedges DS, Bodenhamer C, Brown R, Wheeler $J G$, Kirking H. High COVID-19 attack rate among attendees at events at a church—Arkansas, March 2020. Morb Mortal Wkly Rep. 2020;69(20):632-5. https://doi.org/10.15585/mmwr.mm6920e2.

65. Hamner L, Dubbel P, Capron I, Ross A, Jordan A, Lee J, Lynn J, Ball A, Narwal S, Russell S, Patrick D, Leibrand H. High SARS-CoV-2 attack rate following exposure at a choir practice-Skagit County, Washington, March 2020 Morb Mortal Wkly Rep. 2020;69(19):606-10. https://doi.org/10.15585/mmwr. mm6919e6.

66. Szablewski CM, Chang KT, Brown MM, Chu VT, Yousaf AR, Anyalechi N, et al. SARS-CoV-2 transmission and infection among attendees of an overnight camp—Georgia, June 2020. Morb Mortal Wkly Rep. 2020;69:1023-5. https:// doi.org/10.15585/mmwr.mm6931e1

67. Bullard J, Dust K, Funk D, Strong JE, Alexander D, Garnett L, Boodman C, Bello A, Hedley A, Schiffman Z, Doan K, Bastien N, Li Y, van Caeseele PG, Poliquin G. Predicting infectious SARS-CoV-2 from diagnostic samples. Clin Infect Dis. 2020;71(10):2663-6. https://doi.org/10.1093/cid/ ciaa638.

68. Chang D, Mo G, Yuan X, Tao Y, Peng X, Wang FS, Xie L, Sharma L, dela Cruz CS, Qin E. Time kinetics of viral clearance and resolution of symptoms in novel coronavirus infection. Am J Respir Crit Care Med. 2020;201(9):1150-2. https://doi.org/10.1164/rccm.202003-0524LE.

69. Li R, Pei S, Chen B, Song Y, Zhang T, Yang W, et al. Substantial undocumented infection facilitates the rapid dissemination of novel coronavirus (SARS-CoV-2). Science. 2020;368:489-93.
70. Chen Y, Wang A, Yi B, Ding K, Wang H, Wang J, et al. Epidemiological characteristics of infection in COVID-19 close contacts in Ningbo city. Chinese J Epidemiol. 2020;41:667-71.

71. Centers for Disease Control. COVID-19 pandemic planning scenarios. 2020 https://www.cdc.gov/coronavirus/2019-ncov/hcp/planning-scenarios.html. Accessed 21 Aug 2020.

72. Gostic KM, Gomez ACR, Mummah RO, Kucharski AJ, Lloyd-Smith JO. Estimated effectiveness of symptom and risk screening to prevent the spread of COVID-19. Elife. 2020;9:1-18.

73. Larremore DB, Wilder B, Lester E, Shehata S, Burke JM, Hay JA, et al. Test sensitivity is secondary to frequency and turnaround time for COVID-19 surveillance. Sci Adv. 2020;5393:1-17. https://doi.org/10.1101/2020.06.22.2 0136309.

74. Paltiel AD, Zheng A, Walensky RP. Assessment of SARS-CoV-2 screening strategies to permit the safe reopening of college campuses in the United States. JAMA Netw Open. 2020;3(7):e2016818. https://doi.org/10.1001/jama networkopen.2020.16818.

75. Chin ET, Huynh BQ, Chapman LAC, Murrill M, Basu S, Lo NC. Frequency of routine testing for coronavirus disease 2019 (COVID-19) in high-risk healthcare environments to reduce outbreaks. Clin Infect Dis. 2019;2020:1-3.

76. Roxby AC, Greninger AL, Hatfield KM, Lynch JB, Dellit TH, James A, et al. Outbreak investigation of COVID-19 among residents and staff of an independent and assisted living community for older adults in Seattle, Washington. JAMA Intern Med. 2020;180(8):1101-1105. https://doi.org/10.1 001/jamainternmed.2020.2233.

77. Kimball A, Hatfield KM, Arons M, James A, Taylor J, Spicer K, et al. Asymptomatic and presymptomatic SARS-CoV-2 infections in residents of a long-term care skilled nursing facility-King County, Washington, March 2020. Morb Mortal Wkly Rep 2020;69:377-381, 13, https:/doi.org/10.15585/mmwr.mm6913e1.

78. Viswanathan M, Kahwati L, Jahn B, Giger K, Dobrescu Al, Hill C, et al. Universal screening for SARS-CoV-2 infection: a rapid review. Cochrane Database Syst Rev. 2020;(9). https://doi.org/10.1002/14651858.CD013718.

79. Centers for Disease Control and Prevention. Screening clients for COVID-19 at homeless shelters or encampments. 2020. https:/www.cdc.gov/corona virus/2019-ncov/community/homeless-shelters/screening-clients-respiratoryinfection-symptoms.html. Accessed 13 Feb 2021.

80. Centers for Disease Control and Prevention. Managing investigations during an outbreak. 2020. https://www.cdc.gov/coronavirus/2019-ncov/php/conta ct-tracing/contact-tracing-plan/outbreaks.html. Accessed 11 Aug 2020.

81. Patel M, Lee AD, Clemmons NS, Redd SB, Poser S, Blog D, et al. National update on measles cases and outbreaks - United States, January 1-October 1, 2019. Morb Mortal Wkly Rep. 2019;68:893-96. https://doi.org/10.15585/ mmwr.mm6840e2.

82. R Core Team. R: a language and environment for statistical computing. 2020. https://www.r-project.org/.

83. Liu Y, Gayle AA, Wilder-Smith A, Rocklöv J. The reproductive number of COVID19 is higher compared to SARS coronavirus. J Travel Med. 2020;27:1-4.

84. Davies NG, Kucharski AJ, Eggo RM, Gimma A, Edmunds WJ, Jombart T, et al. Effects of non-pharmaceutical interventions on COVID-19 cases, deaths, and demand for hospital services in the UK: a modelling study. Lancet Public Heal. 2020:5(7):e375-85. https://doi.org/10.1016/S2468-2667(20)30133-X.

85. Fuller T. Isolation helps homeless population escape worst of virus. In: New York Times. 2020. https://www.nytimes.com/2020/12/23/us/coronavirushomeless.html. Accessed 11 Feb 2021.

86. Warth G, Sisson P. Coronavirus outbreak detected at San Diego Convention Center homeless shelter. The San Diego Union Tribune. 2020. https://www. sandiegouniontribune.com/news/health/story/2020-12-10/coronavirusoutbreak-detected-at-san-diego-convention-center-homeless-shelter. Accessed 11 Feb 2021.

87. Smith D. After lag, L.A. homeless sites "overwhelmed" by COVID-19. Los Angeles Times. 2021. https://www.latimes.com/homeless-housing/story/202101-03/homeless-shelters-coronavirus-surge-hospitals. Accessed 11 Feb 2021.

88. Gerda N. Over 400 homeless people infected and one dead from coronavirus outbreaks across 17 shelters in Orange County. Voice of OC 2021. https://voiceofoc.org/2021/02/over-400-homeless-people-infected-a nd-one-dead-from-coronavirus-outbreaks-across-17-shelters-in-orangecounty/. Accessed 11 Feb 2021.

89. Courtemanche C, Garuccio J, Le A, Pinkston J, Yelowitz A. Strong social distancing measures in the United States reduced the COVID-19 growth rate. Health Aff. 2020;39(7):1237-46. https://doi.org/10.1377/hlthaff.2020. 00608. 
90. Prem K, Liu Y, Russell TW, Kucharski AJ, Eggo RM, Davies N, Jit M, Klepac P, Flasche S, Clifford S, Pearson CAB, Munday JD, Abbott S, Gibbs H, Rosello A, Quilty BJ, Jombart T, Sun F, Diamond C, Gimma A, van Zandvoort K, Funk S, Jarvis Cl, Edmunds WJ, Bosse NI, Hellewell J. The effect of control strategies to reduce social mixing on outcomes of the COVID-19 epidemic in Wuhan, China: a modelling study. Lancet Public Heal. 2020;5(5):e261-70. https://doi. org/10.1016/S2468-2667(20)30073-6.

91. Jarvis Cl, Van Zandvoort K, Gimma A, Prem K, Auzenbergs M, O'Reilly K, et al. Quantifying the impact of physical distance measures on the transmission of COVID-19 in the UK. BMC Med. 2020;18:1-10.

92. Baggett TP, Scott JA, Le MH, Shebl FM, Panella C, Losina E, et al. Clinical outcomes, costs, and cost-effectiveness of strategies for adults experiencing sheltered homelessness during the COVID-19 pandemic. JAMA Netw Open. 2020;3(12):e2028195. https://doi.org/10.1001/jamanetworkopen.2020.28195.

93. Lewer D, Braithwaite I, Bullock M, Eyre MT, White PJ, Aldridge RW, Story A, Hayward AC. COVID-19 among people experiencing homelessness in England: a modelling study. Lancet Respir Med. 2020;2600(12):1181-91. https://doi.org/10.1016/S2213-2600(20)30396-9.

94. Furukawa NW, Furukawa NW, Brooks JT, Sobel J. Evidence supporting transmission of severe acute respiratory syndrome coronavirus 2 while presymptomatic or asymptomatic. Emerg Infect Dis. 2020;26:E1-6.

95. Arons MM, Hatfield KM, Reddy SC, Kimball A, James A, Jacobs JR, Taylor J, Spicer K, Bardossy AC, Oakley LP, Tanwar S, Dyal JW, Harney J, Chisty Z, Bell JM, Methner M, Paul P, Carlson CM, McLaughlin H, Thornburg N, Tong S, Tamin A, Tao Y, Uehara A, Harcourt J, Clark S, Brostrom-Smith C, Page LC, Kay M, Lewis J, Montgomery P, Stone ND, Clark TA, Honein MA, Duchin JS, Jernigan JA, Public Health-Seattle and King County and CDC COVID-19 Investigation Team. Presymptomatic SARS-CoV-2 infections and transmission in a skilled nursing facility. N Engl J Med. 2020;382(22):2081-90. https://doi. org/10.1056/NEJMoa2008457.

96. Tindale LC, Stockdale JE, Coombe M, Garlock ES, Lau WYV, Saraswat M, et al. Evidence for transmission of COVID-19 prior to symptom onset. Elife. 2020;9: $1-34$.

97. Arima Y, Kutsuna S, Shimada T, Suzuki M, Suzuki T, Kobayashi Y, Tsuchihashi Y, Nakamura H, Matsumoto K, Takeda A, Kadokura K, Sato T, Yahata Y, Nakajima N, Tobiume M, Takayama I, Kageyama T, Saito S, Nao N, Matsui T, Sunagawa T, Hasegawa H, Hayakawa K, Tsuzuki S, Asai Y, Suzuki T, Ide S, Nakamura K, Moriyama Y, Kinoshita N, Akiyama Y, Miyazato Y, Nomoto H, Nakamoto T, Ota M, Saito S, Ishikane M, Morioka S, Yamamoto K, Ujiie M, Terada M, Sugiyama H, Kokudo N, Ohmagari N, Ohnishi M, Wakita T, the COVID-19 Response Team. Severe acute respiratory syndrome coronavirus 2 infection among returnees to Japan from Wuhan, China, 2020. Emerg Infect Dis. 2020;26(7):1596-600. https://doi.org/10.3201/eid2607.200994.

98. Leung NHL, Chu DKW, Shiu EYC, Chan KH, McDevitt JJ, Hau BJP, et al. Respiratory virus shedding in exhaled breath and efficacy of face masks. Nat Med. 2020;26(5):676-80. https://doi.org/10.1038/s41591-020-0843-2.

99. Maclntyre CR, Chughtai AA. Facemasks for the prevention of infection in healthcare and community settings. BMJ. 2015;350:1-12.

\section{Publisher's Note}

Springer Nature remains neutral with regard to jurisdictional claims in published maps and institutional affiliations.

Ready to submit your research? Choose BMC and benefit from:
- fast, convenient online submission
- thorough peer review by experienced researchers in your field
- rapid publication on acceptance
- support for research data, including large and complex data types
- gold Open Access which fosters wider collaboration and increased citations
- maximum visibility for your research: over 100M website views per year
At BMC, research is always in progress.
Learn more biomedcentral.com/submissions

